\title{
THE APOTHEOSIS OF SITI KHOTIJAH: ISLAM AND MUSLIMS IN A BALINESE GALACTIC POLITY
}

\author{
Mark Woodward \\ Center for the Study of Religion and Conflict \\ Arizona State University \\ $<$ mark.woodward@asu.edu>
}

\section{Introduction}

This article seeks to describe the way in which Gusti Ayu Made Rai, an eighteenth-century Balinese princess from Badung became Raden Ayu Siti Khotijah, one Indonesia's few widely recognized female Muslim saints. In so doing I develop an alternative reading of the dynamics of the history of religion in Bali, countering the common view that it is a static monolithically Hindu tradition. Rather than turning inward as the surrounding areas embraced Islam, Balinese kingdoms sought to include Muslims and elements of Islam in scared narratives and geographies. Two distinct theoretical approaches are used in this analysis: the structural approach to indigenous Southeast Asian states pioneered by Robert Heine-Geldern in the early decades of the twentieth century and the performative approach to ritual studies developed by Victor Turner in the 1970s.

\section{Bali and Orientalist Romanticism}

Bali is often called the "Island of the Gods." As Boone observes representations of Bali have been tinged with romantic longing since the days of the Netherlands East India Company. ${ }^{1}$ Tropes of Rousseau's "noble savage" and a longing for an other than Muslim Indonesia are the implicit subtexts of much of the academic and more, if not most, popular writing about Balinese religion and culture. Bali is often seen as a Hindu island in a sea of Islam and as a fossilized version of what Java, and much of the rest of Indonesia,

1 Boone, J. (1972) The Anthropological Romance of Bali 1597-1972: Dynamic Perspectives in Marriage and Caste, Politics and Religion, Cambridge: Cambridge University Press. 
used to be. ${ }^{2}$ Vickers mentions that the first Dutch mariners to visit Bali in the seventeenth century were pleased to discover that Balinese, unlike Turkish Muslims, ate pork and unlike Portuguese Roman Catholics, did not fast on Fridays. ${ }^{3}$

These cultural similarities led them to conclude (incorrectly) that Balinese kingdoms were natural allies in their struggle against these rivals and Muslim Mataram. ${ }^{4}$ Following Raffles' lead, generations of orientalists and following them anthropologists, described the Balinese aristocracy as refugees from the fall of the Hindu-Javanese kingdom Majapahit to "Goth-like Muslims" in $1478 .^{5}$ This evokes images of the Ottoman conquest of Constantinople a quarter century earlier (1453) and the subsequent siege of Vienna in 1529. Dutch Orientalism constructed an

2 Geertz, C. (1985) Local Knowledge: Further Essays in Interpretive Anthropology. New York: Basic Books.

3 The Ottomans, Portuguese, British and Dutch were the principle rivals for control of the Southeast Asian spice trade at this time. On the Ottoman presence in Southeast Asia see: Peacock, A. and Gallop, A. (2015) From Anatolia to Aceh: Ottomans, Turks, and Southeast Asia, Oxford: Oxford University Press and Bulut, M. (2002) "The Role of the Ottomans and Dutch in the Commercial Integration between the Levant and Atlantic in the Seventeenth Century," Journal of the Economic and Social History of the Orient. Tulips, long iconic of Dutch culture, were originally imported from Ottoman Turkey where they were an important national symbol. See: Theunissen, $\mathrm{H}$, and Roding, M. (eds.) (1993) The Tulip, A Symbol of Two Nations. Utrecht: Istanbul Turco-Dutch Friendship Association Press. The world's greatest spice market was, and still is, in Istanbul.

4 Vickers, A. (1987) "Hinduism and Islam in Indonesia: Bali and the Pasisir World," Indonesia

5 Day, A. (1983) "Islam and Literature in SouthEast Asia: Some Pre-Modern, Mainly Javanese Perspectives," in: Islam in South-Eat Asia, Hooker, M., Leiden: Brill. illusionary text based image of Bali as "Little India" to impede the spread of Islam and the growth of nationalism in much the same way that Raffles constructed an image of a less the Islamic Java in support of his advocacy of an expansionist "forward" policy for the British East India Company in the early nineteenth century. ${ }^{6}$

Romanticized accounts of Balinese religion and culture by Geertz, Lansing and other present it as a tranquil, involuted agrarian civilization obsessed with ritual and the performing arts, self-consciously distancing itself from its political and economic environments and the Islamicate civilizations surrounding it. ${ }^{7}$ Geertz's description of Balinese kingdoms as "theatre states" replicating the Hindu-Balinese cosmos and more concerned with ritual than realpolitik builds on this Orientalist tradition. ${ }^{8}$

Romanticized representations of "exotic" cultures rarely stand up to close scrutiny especially those depicting the "exotic other" as a mystical, artful, alternative to materialist modernity. Vickers, Andaya and other historians

6 Guermonprez, J. (2001) "La Religion Balinaise dans le Miroir de Hindouism," Bulletin de Ecole Frangaise d'Extreme Orient. Smith, B. and Woodward, M. (2014) "Decolonizing Islam and Feminism," in: Smith, B. and Woodward, M. (2014) Gender and Power in Indonesian Islam: Leaders, Feminists, Sufis and Pesantren Selves. London: Routledge.

7 Geertz, C. (1967) "Person Time and Conduct in Bali: An Essay in Cultural Analysis," American Anthropologist. Lansing, S. (1983) Three Worlds of Bali, New York: Praeger.

8 Geertz, C. (1981) Negara: The Theatre State in Nineteenth-Century Bali. Princeton: Princeton University Press. 
have shown that far from being bastions guarding a besieged Indic civilization, pre-colonial Balinese states were actively engaged in commercial and political relations with neighbouring Muslim states. They also supported the development of Muslim communities. According to some accounts Javanese Muslims came to Bali with the Majapahit "refugees." Ironically others were established by Muslim refugees fleeing the Dutch conquest of Makassar. ${ }^{9}$

In this article, I carry this line of analysis a step further, demonstrating that Muslim themes, symbols and at least one saint were incorporated into the sacred geography and symbology of Hindu-Balinese kingdoms. As was true of other Indianized Southeast Asian states in what are now Burma and Thailand, religious others were incorporated into the symbolic orders characterized by the hegemony of a politically dominant religious tradition. To make these points, I rely primarily on performance theory based analysis of the sacred biography Raden Ayu Siti Khotijah and ritual practices associated with her grave and secondarily on observations concerning the sacred geography of Klungkung.

\section{Theoretical Perspectives}

Theoretical myopia is among the challenges confronting ethnological analysis of social and cultural

9 Vickers, A. op. cit. complexity. Dependency on narrow theoretical frames contributes to analytic reductionism. It also leads to neglect of elements of complexity that cannot be captured or explained in terms of a single or small set of variables. Here I rely on a combination of structuralist theory in the analysis of the spatial orientation of HinduBalinese states and performance oriented ritual theory in the analysis of how a Balinese Hindu and Hindu space are transformed to incorporate Muslims and Muslim space. These approaches are united by an overarching complexity theory based model of state systems including three components:

1) Symbologies: institutionalized meaning systems including narratives, symbols and rituals that establish the legitimacy and primacy of the state in religious or ideological ways; 2) Technologies including expenditures on the military and security forces, education, infrastructure and architecture promoting conformity with state symbologies and 3) Identity spaces that includes face to face and imagined communities that support, contest for, or elude state symbologies and technologies. ${ }^{10}$ The failure of the establishment of a woman as an exemplar of Muslim piety to foster social transformations diminishing patriarchal hegemony

10 This is a slightly modified version of a model developed by Liu, Fisher-Onar and Woodward. Liu, J., Fisher-Onar, N. and Woodward, M. (2014) "Critical junctures? Complexity and the Post-Colonial Nationstate, International Journal of Intercultural Relations. 
problematizes feminist theories

predicting that the sacred biographies of female saints inspire feminist praxis promoting women's autonomy and empowerment. ${ }^{11}$

\section{Sacred Geography and Indianized States}

The equation of microcosm and macrocosm in a basic structural principle of what Coedes calls the "Indianized States" of Southeast Asia. ${ }^{12}$ Heine-Geldern and following him generations of anthropologist, historians and political scientists have taken this cosmic equation as a point of departure for exploring the structure and dynamics of indigenous Southeast Asian states. ${ }^{13}$. Throughout the region states, palaces and temples were constructed as mandala, a central point surrounded by multiples of four at cardinal and sub-cardinal directions, replicating of Buddhist or Hindu cosmologies. Kings were held to be incarnations of Hindu gods (Devaraja) or just kings who rule in accordance with Buddhist teachings (Dharmaraja). ${ }^{14}$ They were and are

11 Vintges, K. (2004) "Endorsing Practices of Freedom," in: Taylor D. and Vintges, K. Feminism and the Final Foucault, Urbana: University of Illinois Press. 12 Coedes, G. (1968) The Indianized States of Southeast Asia. Honolulu: University of Hawaii Press. 13 Heine-Geldern, R. (1930) “Weltbild und Bauform in Südostasien'," Wener Beitrage zur Kunst- und Kulturgeschichte Asiens. (1956) Conceptions of Sate and Kingship in Southeast Asia, Ithaca: Cornell University Southeast Asia Program.

14 On Devaraja see: Kulke, H. (1978) The Devaraja Cult. Ithaca: Cornell University Southeast Asia Program. On Dharmaraja see: Smith, B., (ed.) 1978. Religion and Legitimation of Power in Thailand, Laos, and Burma, Chambersburg: ANIMA. what Tambiah calls "Galactic Polities." He describes them as totalizing institutions in which administrative and other aspects of state technologies and identity spaces are subordinated to and structured in terms of state symbologies. ${ }^{15}$ Balinese states were exceptional case only because of the extent to which this pattern of spatial orientation pervades daily life. ${ }^{16}$

Some Muslim states including the contemporary Sultanate of Yogyakarta in Indonesia and Negeri Sembilan in Malaysia preserve this pattern of spatial orientation. ${ }^{17}$ Southeast Asian states were, however, more than replicas of Indian textual prototypes. In most instances, Southeast Asian Galactic Polities absorbed elements of nondominant religions as components of sacred geography and state ceremonies. In Burma, indigenous spirits (nat), some believed to be reincarnations of foreign Muslims figured significantly in sacred geography and popular Buddhist piety. ${ }^{18}$ In both Burma and Thailand

15 Tambiah, S. (1973). "The Galactic Polity in Southeast Asia." In Culture, Thought, and Social Action, Cambridge: Harvard University Press. (1977) World Conqueror and World Renouncer: A Study of Buddhism and Polity in Thailand against a Historical Background. Cambridge: Cambridge University Press.

16 Hauser-Schäublin, B. (2004) "The Politics of Sacred Space; Using Conceptual Models of Space for Sociopolitical Transformations in Bali," Bijdragen tot de Taal-, Land- en Volkenkunde.

17 Andaya, B. and Andaya, L. (2016) A History of Malaysia, New York: Palgrave Macmillan, Moertono, S. (1968) State and Statecraft in Old Java. Ithaca: Cornell University Modern Indonesia Project. Woodward, M. (2011) Java, Indonesia and Islam. New York: Springer. 18 Brown, G. (1915) The Taungbyon Festival, Burma, The Journal of the Royal Anthropological Institute of Great Britain and Ireland; Spiro, M. (1967) Burmese Supernaturalism, Englewood Cliffs: Prentice Hall; 
Hindu Brahmins played vital roles in state ceremonies. This still the case in the modern Thai kingdom. ${ }^{19}$ In Burma descendants of court Brahmins are highly regarded as astrologers. The 15th-18th century Arakanese kingdom Mrauk U carried this integrative tendency further than most. While it was primarily Buddhist, Muslim scholars and symbolism were fully incorporated into the royal cult of glory. ${ }^{20}$ It should, therefore, come as no surprise that Balinese kingdoms drew on Muslim as well as Hindu sources of legitimacy and provided for the establishment of Muslim shrines and communities, and in so doing, establishing multi-religious Galactic Polities. In this paper, I explore some of the ways in which this principle of inclusion operated in Badung and Klungkung.

\section{Ritual and Social Transformations}

Victor Turner is known best for his theories of the transformative power of ritual and social dramas. Rites of passage are rituals that move people from one position to another in welldefined social structures. Social dramas transform societies at critical junctures in social and political history. Critical

Woodward, Mark (1988), "When One Wheel Stops: Theravada Buddhism and the British Raj in Upper Burma," Crossroads.

19 Quaritch-Wales, H. (1931) Siamese State Ceremonies: Their History and Function. London: Bernard Quaritch.

20 Gutman, P. (1986) "Symbolism of Kingship in Arakan," in: Marr, D. and Milner, A. Southeast Asia in the 9th to 14th Centuries, Singapore: Institute for Southeast Asian Studies. junctures are points in time where significant reconfiguration of system parameters is possible, necessary and in some cases inevitable. They range for critical points in the lives of important individuals to cataclysmic events such as state failures leading to the reconfiguration of social systems.

Rites of passage are common to most all cultures. They mark critical transitions in the life cycle including birth, puberty, marriage and death. Analogous rituals mark entry into structured social groups ranging from the military to social clubs. Turner describes three phases common to most rites of passage: 1) separation, in which previously existing social roles and bonds are dissolved, 2) a period of liminality marked by the absence of well-defined social roles in which initiates receive instruction, and 3 ) reintegration where they assume new social roles. ${ }^{21}$ This model can also be employed in the analysis of religious conversion. Here I use it to explain the process through which Gusti Ayu Made Rai became not only a Muslim but also an exemplary Muslim woman and a saint or 'friend of Allah'.

In his analysis of social dramas Turner develops an anthropological theory of social transformation based on the performative structure of conflict situations. ${ }^{22} \mathrm{He}$ argues that these

21 Turner, V. (1969) The Ritual Process: Structure and Anti-Structure, Chicago: Aldine.

22 Turner, V, (1980) Dramas, Fields and Metaphors: Symbolic Action in Human Society. Ithaca: Cornell 
processes operate below the level of consciousness and that they are at least nearly human universals. His model includes four stages: 1) breach; 2) crisis; 3 ) redress; and 4) reintegration. $\mathrm{He}$ is especially concerned with the third phase, which he stated is characterized by reflexivity. Here social actors reconsider the structure of social relations and institutions and consider options for reintegration. Turner's model is both incomplete and overly optimistic because it does not allow for the possibility that reflexivity and redress may fail, leading to the renewal of conflict or that the social restructuring it produces will sow the seeds of future conflict. Another less than optimal outcome is that reintegration efforts will become irrelevant because of unforeseeable social or political change. This appears to be the true in the case of Siti Khotijah. The seventeenth century restructuring of the sacred geography and symbology of Badung does not provide an adequate model for maintaining Hindu-Muslim congeniality in contemporary Bali.

\section{Gusti Ayu Made Rai - Balinese Princess and Muslim Saint}

Gusti Ayu Made Rai or Raden Ayu Siti Khotijah was a princess from the kingdom of Badung. In what is now the Denpasar area. She became one of the few widely recognized female Muslims

University Press. saints (wali) in Indonesia. Her grave is a popular pilgrimage site for Hindus as well as Muslims. There are thousands, perhaps tens of thousands, of Muslim holy (keramat) graves in scattered throughout Indonesia. It is difficult to overstate the importance of pilgrimage (ziyarah) to sacred graves in traditional Southeast Asian Islam. Some graves are of only local significance. Others, especially those of the Wali Songo, the nine saints instrumental in establishing Islam as the religion of Java, attract millions of pilgrims from throughout Indonesia and neighbouring countries including Brunei, Malaysia and Singapore. Women are buried at many of these shrines but most often because they are the wives or daughters of the male saint. Quinn estimates that there are no more than a dozen widely recognized women saints in all of Indonesia. $^{23}$

Some shrines include the principle saint's grave, surrounded by hundreds of others, usually those of his family members and devotees. Others, including Siti Khotijah's include only a single grave. The fact that there is a steady stream of buses bringing pilgrims from East Java as well as Bali indicates that she has become a national phenomenon. Her tomb is located in a walled compound inside a Hindu cemetery in the Pemecutan district of Denpasar. It is known as "Keramat

23 Quinn, G. (2012) "The Veneration of Female Saints in Indonesia," in: Joseph, S. et. al. (eds.) Encyclopaedia of Women and Islamic Cultures. Leiden: Brill. 
Agung Pemecutan" (The Great Holy Place of Pemecutan).

There are several versions of her sacred biography. ${ }^{24}$ I rely primarily on one included in a booklet by Mangku I Made Puger and conversations with him. He is the current caretaker (juru kunci) of the shrine and distributes the booklet to Muslim and Hindu pilgrims. I supplement these accounts with materials collected from Muslim and Hindu pilgrims. The section of the text describes Gusti Ayu Made Rai and can be analysed as a rite of passage. It begins with a description of her social position as a Balinese Hindu princess and a health crisis that led to her transformation into a Madurese Muslim queen.

Raden Ayu Siti Khotijah was born Gusti Ayu Made Rai or Raden Ayu Pemecutan in the mid-seventeenth century. She was the daughter of the Balinese king of Badung, I Gusti Ngurah Gede Pemecutan, who was also the founder of the modern city of Denpasar. The exact dates of her birth and death are not known. There are at least two accounts of how she came to be a Muslim. The one most commonly

24 I refer to this as a "sacred biography" because it cannot be independently verified. Historians are inclined to dismiss scared biographies as "pious fictions." Regardless of the degree to which they include accurate accounts of the lives of actual individuals, they are enormously important in the lived experience of religion. People who value them do not merely believe them to be true. They know them it be factual. On the concept of sacred biography see: Heffernan, T. (1992). Sacred Biography: Saints and Their Biographers in the Middle Ages. Oxford: Oxford University Press. told to Muslim pilgrims visiting her grave and which is included in Mangku I Made Puger's booklet is:

When she was a young woman, Raden Ayu Pemecutan became seriously ill with hepatitis. None of the Balinese healers could cure the disease. They tried various traditional medicines including antidotes for poison and efforts to combat sorcery, but none of them were successful. ${ }^{25}$ The king went to meditate (tapa semadi) at a holy place located inside the palace. He received a pawisik (message) that he should hold a competition to see who could cure his daughter. The following day he ordered the prime minister to prepare an announcement of a competition not only for the people of Badung, but also for all of Bali and kingdoms outside Bali. The announcement sated: "Whoever can treat and cure my child: If it is a woman she will be the king's adopted daughter. If it is a man and the two are soul mates they will be married."

This came to the attention of an ulama/syech from Yogyakarta. This ulama was a person with great mystical knowledge (ilmu kebatinan). Pangeran Cakrangingrat IV (1718-1746) of the Madurese kingdom of Bangkalan was his student and close associate. ${ }^{26}$ The

25 Another version of the story does not mention the miraculous healing and states that the king gave Raden Ayu Pemecutan in marriage to the Madurese prince after he provide assistance in a war against a rival kingdom.

26 The Sultanate of Yogyakarta was not established until 1755 . 
syech sent him a message instructing him to come to Yogyakarta as quickly as possible. After receiving the message from his teacher, Pangeran Cakrangingrat came to Yogyakarta with forty soldiers. When he arrived, the prince appeared before his teacher and asked him what had happened. The syech told him what he had received a message from the King of Pemecutan in Bali. He then ordered the prince to go to Bali to meet the king.

Pangeran Cakrangingrat IV said farewell to and asked for blessing (pamit dan mohon doa restu) from his teacher before leaving for Bali. When he arrived at Pemecutan he presented himself to the king, who received him warmly. The prince asked what had happened and how he could help. The king explained that his daughter Gusti Ayu Made Rai had been suffering from hepatitis for several years. He asked if the prince could treat and cure the illness his daughter was suffering from. The prince replied that he would do what the king had asked. ${ }^{27}$

The king summoned his beloved daughter and introduced her to Pangeran Cakrangingrat. From the moment she met him the princess's heart trembled and the treatment began. After several treatments, the illness she had suffered

27 Vickers op. cit. mentions that in some areas in Bali Muslims are highly regarded as healers. It seems unlikely that a monarch would have undertaken such a journey. The tale is however congruent with Balinese understandings of Muslims as healers. It is reasonable to suggest that the ranks and titles of some of the characters in the story were inflated to enhance its prestige. from for years began to be cured. She revealed the feelings of her heart to her father.

\section{The king called Pangeran}

Cakrangingrat to appear before him and in their meeting thanked him for his help treating and curing his daughter and asked if he had fallen in love with her. Pangeran Cakrangingrat replied that from their first meeting he had been entranced with the princess and that he loved her. Recognizing that their feelings were the same, the two were married in the Pemecutan palace in the presence of the prince's forty bodyguards and the entire royal family of Pemecutan.

Her marriage and journey to Madura with her husband marks the first of the stages, separation, in Turner's model of rites of passage. In this instance, the separation is geographic, out of Bali, and socio-religious, out of Hinduism.

The prince then asked permission to return to Bangkalan with his wife.

What follows is the second, liminal, phase in which she learns about Islam. This is not described in detail. It is simply stated that:

Gusti Ayu Made Rai became a Muslim and changed her name to Raden Ayu Siti Khotijah. ${ }^{28}$

Her reincorporation and subsequent new position as a proper seventeenth century Muslim woman are described in

28 The name chose for her was that of the Prophet Muhammad's first wife Khadijah who is commonly known as the "Mother of the Believers." 
greater detail.

After embracing Islam, she became very devoted the Shari'ah including praying five times per day. Even though she was Pangeran Cakrangingrat's fourth wife, she lived harmoniously with the others. As a Muslim, she was very devoted to pengajian (religious talks) dakwah (propagation of Islam) and other religious activities. ${ }^{29}$

\section{Social Drama and Siti Khotijah - Setting the Stage}

The next section of the text sets the stage for the social drama leading to the reconfiguration of Bandung's symbology. The stage for this social drama is the palace (puri) of Badung. The sacred geography of a Balinese palace is based on the kahyangan tiga (three temples) system that also structures villages and domestic compounds. It includes three principle shrines: 1) The household shrine or temple of origin (pura puseh) where purified ancestors are located; 2) Living quarters (pura desa) and 3.) The death temple/cemetery (pura dalem). They are structured by a hierarchy of purity, the most impure being the pura desa and the purest the pura puseh. The pura desa occupies an intermediate position. ${ }^{30}$ Hobart shows that the life cycle is conceptualized as movement from the pura puseh where rites for

29 Here she is depicted as the ideal traditional Muslim woman. Wives living harmoniously in plural marriages is an ideal that is frequently not a social reality.

30 Hauser-Schäublin op. cit. new-borns a performed, through the pura desa where the child comes to adulthood and with death to the pura dalem. The maligia ritual is performed to purify the souls of the dead, often long after they have been cremated, and return them to the pura puseh.

After living with her husband for many years she finally became homesick for the father, mother and family. She came before her husband to ask his blessing and permission to visit them. Pangeran Cakrangingrat understood her desires very well. Although he had heavy duties and obligations he granted Raden Ayu Siti Khotijah permission to visit her father, mother and family in Pemecutan. He ordered some of his bodyguards and ladies of the court to accompany her on the journey to Bali. Forty of these male and female attendants accompanied Raden Ayu Siti Khotijah on her journey even though Pangeran Cakrangingrat did not. Before Raden Ayu Siti Khotijah left he gave her a ceramic jar, a keris (dagger) and several pusaka (sacred heirlooms) that she concealed in her hair. Then Raden Ayu Siti Khotijah and her companions left on their journey to Bali.

At the time Raden Ayu Siti Khotijah left Bangkalan to visit Bali, the Pemecutan kingdom was preparing for the large maligia ritual the purpose of which is to purify the spirits of the dead. This was an auspicious time for 
her to visit and meet with her family. ${ }^{31}$ When she and her companions arrived in Pemecutan her family greeted them warmly. Raden Ayu Siti Khotijah slept in the palace (pura desa) while her companions stayed in the adjacent courtyard.

A breach, the first stage in Turner' model of social drams, occurs because there is no place for Muslim piety in the confines of Hindu-Balinese sacred space. Siti Khotijah's attempt to appropriate the Badung pura puseh for Muslim purposes leads to the illusion of a symbolic reversal in which Muslim piety is (mis) understood as Balinese sorcery. ${ }^{32}$

Because she had become a Muslim, when the time for the evening prayer (maghrib) came, she prayed in the sacred place (pura puseh) inside the palace. She prayed wearing a white mukena (women's prayer garment) facing west in the direction of the kiblat (Mecca). The prime minister saw her praying without a prayer rug. What he saw surprised him because very few people in Bali had ever seen a Muslim pray. The prime minister thought that she was practicing black magic (ilmu hitam/ngeleak). ${ }^{33}$

31 See: Wiener, M. (1994) Visible and Invisible Realms: Power, Magic and Colonial Conquest in Bali, Chicago: University of Chicago Press.

32 On symbolic reversal and witchcraft see: Babcock, B. (ed.) (1978) The Reversible World: Symbolic Inversion in Art and Society, Ithaca: Cornell University Press. On witchcraft and symbolic reversals see: Ginzburg, G. (2013) The Night Battles: Witches and Agrarian Cults in the Sixteenth and Seventeenth Centuries, Baltimore: Johns Hopkins University Press. 33 Balinese believe than many physical and mental
A crisis, the second stage in Turner's model, ensues when Siti Khotijah's breach of Hindu Balinese custom and intrusion of Muslim ritual into Hindu space is discovered. Her father responds in a violent manner, though one appropriate given the religious assumptions on which Balinese concepts of sacred space are based.

The prime minister reported what he had seen to the king. After he received the report and then saw her praying himself, the king was very angry. Without asking Raden Ayu Siti Khotijah what she was doing, he ordered the prime minister to take her to the graveyard (pura dalem) together with the bodyguards and the female companions who had come with her from Bangkalan.

The critical redress/reflexivity stage commences when she responds to her father's accusations and acquiesces to his verdict.

When they arrived at the graveyard, Raden Ayu Siti Khotijah addressed the prime minister:

My uncle the prime minister, I have the feeling, I already know, that I have

illnesses are caused by witchcraft. Intense fear of witches (leyak) is common in all social strata. Conflict between Rangda, the queen of the leyak, and Barong, a lion spirit, is a common theme in Balinese literary and performance traditions. Stephen, M. (1999) "Witchcraft, Grief, and the Ambivalence of Emotions," American Ethnologist. Mead, M. and Bateson, G. (1951) Trance and Dance in Bali. Washington DC: United States Library of Congress. Rangda is usually depicted as a woman very long flowing white hair that could be confused with a mukena. A leyak practicing black magic in the pura puseh is a symbolic reversal that Balinese might well find horrifying 
been brought here to be killed. Because this is my father's order as the king and authority, please, uncle prime minister, carry out his order.

"Know uncle prime minister that I was praying in the holy place according the practice of the religion that I believe in, Islam. I was fulfilling the ritual requirements of my religion".

This was her message to the prime minister:

Do not kill me with a sharp weapon because I cannot be killed in that way. Instead use my hairpin. It has been wrapped in a betel leaf decorated with the colours of the Tri Datu - black, white and red. (This symbolizes the three Hindu gods: Brahma, Visnu and Siva). ${ }^{34}$

Stick it in the left side of my chest. After I am dead, smoke will come out from my body. If it smells bad, please uncle prime minister, just bury me. But if the smoke that comes out of my body smells sweet, please build me a holy place to be known as keramat.

After Raden Ayu Siti Khotijah said this and had conveyed her message to the prime minister she gave the hair pin to him. She raised her hands in sembah (both hands held together in front of the face) to Allah. She asked the prime minister to stab the left side of her chest with the hairpin.

This indicates that Siti Khotijah understood that the incompatibility of Muslim piety and Hindu sacred geography. She accepts death but in so doing proposes restructuring the

34 This is the only reference to Hindu concepts in the text.
Badung galactic polity. ${ }^{35}$

Then, the prime minister stabbed her in the left side of the chest with the hairpin. She fell down, breathing her last breath. Very sweet smoke smelling like honey and Arabian incense came from her body and filled the entire Badung graveyard that is eleven hectares in size so that it smelled very sweet. ${ }^{36}$

This passage shows that Raden Ayu Siti Khotijah has become not just a Muslim, but also a saint. She did not fear, and indeed embraced, death and had at least limited powers of invulnerability. This is in keeping with Javanese and Madurese traditions concerning the invulnerability of saints and the teachings of many Sufi masters who understood death as a step on the journey to Allah. Schimmel quotes the ninth century woman saint Rabia al Alawiyya in her comments on Sufi understandings of death.

"Rabia taught that the believers should love God not from hope or fear but for the sake of his own eternal beauty: out of pure love. "The lovers of God no longer dreaded death but rather longed for it, for death is a bridge that leads the lover to the beloved." ${ }^{37}$

The idea that the bodies of saints are fragrant, smelling of flowers and incense is also deeply rooted in Middle

35 This type of confusion would not have happened in Klungkung because there is a mosque located inside the palace.

36 An alternative version of the story is that she was stabbed in the back with a spear.

37 Schimmel, Anne M. (2001) Rumi's World: The Life and Work of the Great Sufi Poet, Boulder: Shambhala Publications. 
Eastern and Southeast Asian Sufism. ${ }^{38}$ It is often said that the bodies of Muslim saints smell of flowers and incense a belief that can be traced to Prophetic traditions about the fragrance of the Prophet Muhammad. ${ }^{39}$ Javanese Sufi texts and tradition also mention the limited invulnerability of the fifteenth century saintly martyr Syech Siti Jenar and sweet smell of his corpse. ${ }^{40}$ The smell of incense (menyan) and flowers is associated with purity and holiness. Pilgrims visiting holy graves often burn it. This would also appear to connect the story of Raden Ayu Siti Khadija's death with the Balinese Hindu maligia ritual. There is, however, a stark contrast between the fragrance of her body (purity) and the foul smell of Balinese cemeteries that are used as cremation grounds (impurity). ${ }^{41}$ However, Siti Khadija's spirit does not require purification because she has become a saint and has been purified in life in

38 Asher, B. (2009) "The Sufi Shrines of Shahul Hamid in India and Southeast Asia," Artibus Asie.

39 Thurlkill, M. (2016) Sacred Scents in Early Christianity and Islam. Lexington: Lexington Books.

40 Syech Siti Jenar is sometimes considered to have been one of the Wali Songo. He was executed for openly proclaiming the mystical truth of Ibn alArabi's teaching of wahdat al-wujūd, the unity of the divine essence and the human soul, Hadisuwarno, S. (2018) Biografi Lengkap Syekh Siti Jenar, Yogyakarta: Laksana. In this respect, Siti Jenar resembles Mansur al-Hallaj, the Persian Sufi executed in Baghdad in 922. There is not, however, a direct historical connection between them, according to Michael Feener (1998) "A Re-examination of the Place of al-Hallaj in the Development of Southeast Asian Islam," Bijdragen tot de Taal-, Land- en Volkenkunde.

41 Balinese bury their dead until they have sufficient resources to cremate them. When a wealthy and powerful person is cremated, the bodies of relatives and retainers are often cremated with him/her. ways that are not possible in Balinese Hinduism.

Reintegration, the final stage in Turner's model, involves the construction of purified Muslim space within the defile space of the Hindu pura dalem. It transforms Badung symbology by creating a Muslim enclave in the Hindu-Balinese Galactic Polity. It also redefines the identity space of the Balinese kingdom through the creation of formally recognized Muslim residential spaces.

Some of the people who accompanied her cried hysterically and others fainted. Later that evening Muslim funeral prayers were held and her body was buried. When this was finished the prime minister and Raden Ayu Siti Khotijah's companions presented themselves to the king of Pemecutan. The prime minister conveyed Raden Ayu Siti Khotijah's words and the message she gave before she died to the king.

The king appointed a juru kunci (care taker) for her grave and ordered that he and his descendants should care for it.

The man chosen for these tasks was a Hindu. The current caretaker, Mangku I Made Puger, is the grandson of the first juru kunci. Like his father and grandfather, he is a Hindu. He takes his responsibility to care for the grave and meet the needs of Muslim pilgrims very seriously. He explained that he travelled to East Java to "learn how to care for 
Muslim graves." Put in theoretical terms he learned the modes of ritual practice appropriate for Muslim sacred space.

The bodyguards and female attendants did not return to Bangkalan in Madura. They were given land to settle on in the area that is now Kampung Jawa in North Denpasar and Kampung Islam Kepaon in South Denpasar. ${ }^{42}$

The day after she died, Raden Ayu Siti Khotijah's grave was cleaned and the new juru cunci and his wife covered it with the flowers used at Javanese and Madurese Muslim graves. That night there was an unexpected miracle. A tree approximately fifty centimetres tall grew from Raden Ayu Siti Khotijah's grave. The next morning the juru cunci and his wife cut it down, but it grew back the next night at the same size and in the same place. This happened three times. They were not brave enough to cut the tree that grew from Raden Ayu Siti Khotijah's grave again. That night the juru kunci and his wife meditated (terakat/bersemedi) at the grave. While meditating they heard Raden Ayu Siti Khotijah's voice and received a message from her.

She said that the tree that had grown from the middle of her grave should be cared for because it had grown from her hair and that Allah

42 Muslims from Java, Sulawesi and other parts of Indonesia have settled in these kampung. Islam and Muslims were integrated into the sacred space of KlungKlung is a more systematic way. There, the palace is surrounded by concentric circles of alternating Hindu and Muslim villages. would grant miracles (mukjizat) and blessing (rejiki) to his communities (umat) that perform pilgrimage (berziyarah) to her grave. Because of this message the tree has be honoured and well cared for. It is now known as the Pohon Rambut (Hair Tree).

The tree is approximately 16 meters tall. Like Raden Ayu Siti Khotijah's grave, it is sacred (keramat). It is said that its leaves never fall on the grave and that they have medicinal properties. Mangku I Made Puger collects them and gives them to Hindu and Muslim pilgrims.

\section{Grave Complex: Containing Muslim Space}

The grave complex is located within the Badung pura dalem. Like other Balinese cemeteries it is overgrown with tree and brush and has the appearance of being abandoned. In contrast, the compound including Raden Ayu Siti Khotijah's grave is carefully maintained. The grave complex includes two walled compounds.

The outer compound is liminal space. It is a passageway from the defiled Balinese Hindu space of the pura dalem to the purified grave site that can be understood as a distinctively Muslim pura puseh. This entryway is mixed Hindu-Muslim space. There are signs indicating that it is the entry to Siti Khotijah's grave, but it is a site for Hindu or at least Hindu style devotions. There are statues of Hindu guardian 




Picture 1. Hindu Guardian Spirit Outer Compound

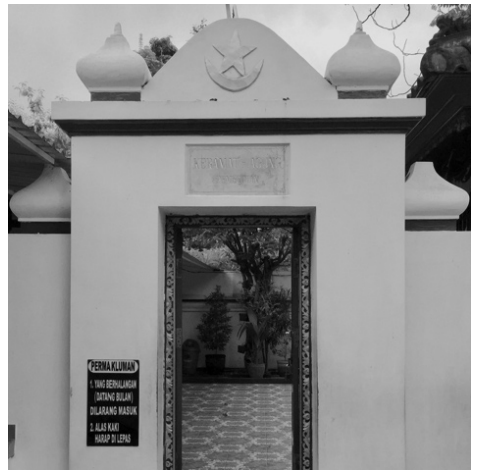

Picture 2. Entrance to the Inner Compound (The inner compound and the gate leading to it are Muslim space.

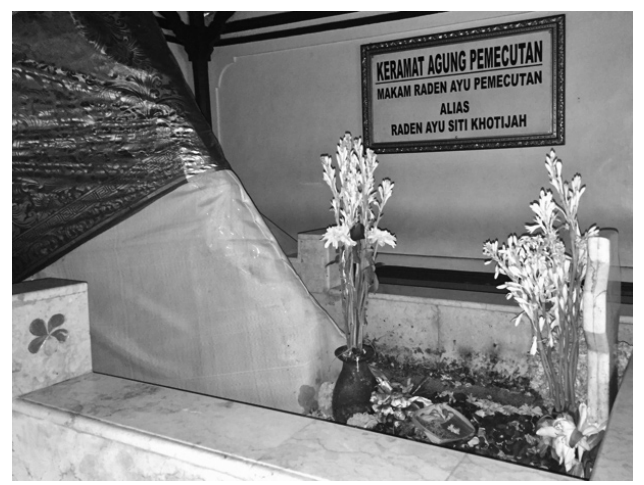

Picture 3. Siti Khotijah's Grave with Base of the Hair Tree

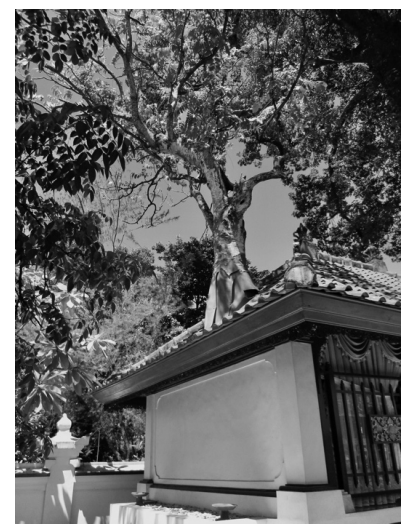

Picture 4. The Hair Tree

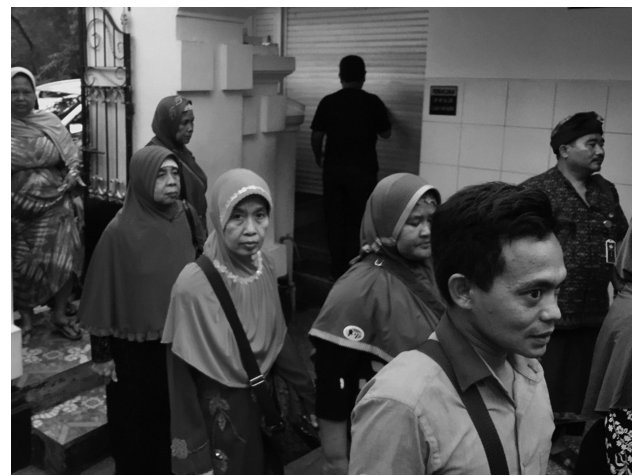

Picture 5. Muslim Pilgrims from East Java

spirits. Daily offerings (canang sari) made to them are distinctively Balinese. They do not resemble those typically presented to spirits in Java (sajen).

They are almost indistinguishable from Muslim graves in Java, Madura, elsewhere in Indonesia and those in Muslim societies in Africa, the Middle East and South Asia. The only distinctive feature of Siti Khotijah's grave is the "hair tree" that has grown through the roof of the enclosure.

The ritual practices associated 
with ziyarah to the grave are entirely conventional, including tahlil - rhythmic recitation of the first phrase of the Muslim Confession of Faith (shahada) La ilaha illa Lah (There is no god but God) reciting or reading Surah Yasin of the Qur'an and $d o^{\prime} a$ (supplications asking Allah for assistance), burning incense and scattering red and white flowers on the tomb. ${ }^{43}$ Only Muslim pilgrims engage in these practices. Hindu pilgrims pay their respects with a sembah. There is no apparent blending of devotional practices as there are at some HinduMuslim shrines in India. ${ }^{44}$ Hindus visit an unambiguously Muslim shrine primarily because of its healing powers.

\section{Contemporary Pilgrimage Practices}

In the eighteenth-century narratives concerning Siti Khotijah and incorporation of her grave into the Badung Galactic polity were local or at most regional Balinese phenomena. Colonialism, post-colonial nation building and internal migration have transformed Balinese identity spaces. Bali is far less culturally and political autonomous than it was in the eighteenth century. At least fifteen percent of the population is now

43 The practices are remarkably uniform across otherwise vastly different Muslim cultures. I have observed them throughout Southeast Asia, in Niger and Nigeria in West Africa and in the United Kingdom. 44 Gold, D. (2005) "The Sufi Shrines of Gwalior City: Communal Sensibilities and the Accessible Exotic under Hindu Rule," Journal of Asian Studies.
Muslim. In Denpasar, some estimates place it as high as twenty five per cent. Economic opportunity resulting from the development of Bali as global tourist destination sparked a wave of Muslim immigration from East Java, Lombok and Madura beginning in the mid 1980s. This has led to the nationalization of pilgrimage to Siti Khotijah's grave and the development of a Bali based Muslim pilgrimage network.

Muslim and Hindu Balinese visit Siti Khotijah's shrine individually or in small groups. These pilgrimages are especially common during Ramadan. Larger groups of Balinese Muslims and others from Java, Lombok, Madura and Sulawesi come to celebrate her birthday. It includes a large slametan (prayer meal) similar to those held in Java. Objects that belonged to Raden Ayu Siti Khotijah including her prayer rug, sandals, and other personal items that are said to be charged with barakah (blessing) are displayed on these occasions. ${ }^{45}$ The date of these celebrations is fixed by the Balinese Pkuwon calendar and occurs every 210 days.

There are larger organized pilgrimage tours from Java and Sulawesi. Muslim religious leaders organize some of these. Travel agencies specializing in pilgrimage tourism

45 The practice of displaying items belonging to the saint is common throughout the Muslim world. Swords and other items belonging to the Prophet Muhammad and his companions are on display at the Topkapi palace in Istanbul. Jalaluddin Rumi's caps and sandals are displayed at his shrine in Konya. 
organize others. The Balinese provincial government actively encourages Muslim pilgrimage as part of its tourism promotion efforts. As many as twenty of these tours, each of which includes as many as two hundred pilgrims/tourists, visit the shrine every week. Many of these tours also visit other Muslim holy sites in Bali, especially the graves of the Wali Pitu (seven saints) who are said to have been influential in spreading Islam in Bali. Internationally renowned Muslim leaders including Syech Hisham Kabbani of the transnational Naqshbandi Haqqani Sufi order have also visited the shrine. ${ }^{46}$ As many as twenty of these tours, each of which includes as many as two hundred pilgrims/tourists, visit the shrine every week. Many of these tours also visit other Muslim holy sites in Bali, especially the graves of the Seven Wali who were influential in bringing Islam to Bali.

Pilgrimage to the graves of the Wali Pitu (seven saints) emerged in the 1990s. These saints were discovered and promoted by Toyib Zain Zaen Arif, an Indonesian Muslim of Hahdrami Arab descent from East Java. ${ }^{47}$ His program had as much to do with bringing Bali into Javanese and

46 Syech Hisham Kabbani has large followings in Indonesia, Malaysia and Singapore. He visits Southeast Asia on a regular basis

47 Slama, M. (2014) “From Wai Songo to Wali Pitu: The Traveling of Islamic Saint Veneration to Bali," in: Hauser-Schäublin, B. and Harnish, D. (2104) Between Harmony and Discrimination: Negotiating Identities within Majority-Minority Relationships in Bali and Lombok, Leiden: Brill.
Hahdrami Islamic identity paces as with bringing Islam into Balinese identity space. ${ }^{48}$ The Wali Pitu are modelled on the Javanese Wali Songo (nine saints), most of whom are believed to have been of Hadhrami descent, who were instrumental in establishing Islam as the religion of Java. Unlike Siti Khotijah, the Wali Pitu do not have roots in Balinese history and tradition and are more closely associated with Javanese tradition. All but one is said to have been Hahdramis. The seventh is said to have been an Indonesian Muslim of Chinese descent.

\section{Sacred Space, Religious Pluralism and Social Integration}

The transformation of Badung's Galactic Polity to include Muslim space was a premodern effort to incorporate a small Muslim minority into a Hindu polity. It promoted what Eck calls civic pluralism that allows religious communities to coexist while disagreeing on basic religious issues. ${ }^{49}$ It requires constructing or transforming symbologies and technologies that accommodated and legitimize identity spaces characterized by ethnic and/or

\footnotetext{
48 On Hadhrami Islam in Indonesia see: Alatas, F. (1997) "Hadhramaut and the Hadhrami Diaspora: Problems in Theoretical History," in: Freitag, W. (1997) Hadhrami Traders, Scholars and Statemen in the Indian Ocean 1750s-1960s, Leiden: Brill and Woodward, M., Rohmaniyah, I., Amin, A., Ma'arif, S., Murtaugh Coleman, D. and Umar, S. (2013) "Commanding the Good or Forbidding the Evil? Hahdrami Dakwah in Contemporary Indonesia," Review of Malaysian and Indonesian Affairs.
}

49 Eck, D. (2007) "Prospects for Pluralism: Voice and Vision in the Study of Religion" Journal of the American Academy of Religion. 
religious diversity. Constructing Muslim space within the Badung Galactic Polity served this purpose. The integration of Hindu and Muslim sacred space and shared pilgrimage traditions approaches what Eck calls theological pluralism in which people of different faiths come to share religious assumptions and at least limited truth claims. Here, it is also important to note that the story of her death could have been, but was not, frame as a martyrdom narrative. She is instead depicted as a Muslim saint whose spiritual powers benefit Hindus as well as Muslims.

There are some Balinese Hindus, including Mangku I Made Puger, who believe that greater recognition of Siti Khotijah could promote tolerance and pluralism in modern Bali. A local government website from Sukolilo Baru where her grave is located states: ${ }^{50}$

"The sacred grave at Pemecutan is a Muslim grave located in the middle of a Hindu cemetery in Pemecutan in Denpasar. This grave is that of a descendant of the king of Pemecutan. It is holy for both Hindus and Muslims. This grave is also a symbol of how communities with different religious beliefs can be united. Neither Hindus nor Muslims claim exclusive understandings. They are like two colours brought together in one pot. The situation at the grave of Siti Khotijah is a tool for unifying Muslims with Hindus, who are the majority religion on the island of Bali."

This is perhaps an overly optimistic assessment. The provincial government and much of the Balinese Hindu establishment now promote a more exclusivist Hindu identity based on religious homogeneity and a return to the "true" Bali. ${ }^{51}$ This nativist symbology allows for a more limited form of pluralism in which other religions, and especially Islam, are relegated to parallel but subordinate positions. The subordination of Islam is apparent in difficulties Muslims have securing permission to build mosques. Parallel pluralism is expressed symbolically in the Puja Mandala, a religious complex in Kuta that includes Roman Catholic and Protestant Churches, a Buddhist Temple, a Mosque and a Hindu Balinese Temple. It is designed to represent a type of civic pluralism based on peaceful coexistence of firmly bounded traditions rather than the integrative theological pluralism of Siti Khotijah's tomb complex.[]

51 Rhoads, E. (2007) “Bali Standing Strong”, Inside Indonesia. 